УДК 633.85:631.5(477.7)

DOI https://doi.org/10.32848/agrar.innov.2021.5.11

\title{
ОПТИМІЗАЦІЯ ПРОДУКЦІЙНОГО ПРОЦЕСУ АГРОЦЕНОЗІВ СОНЯШНИКУ ЗА ПОСУШЛИВИХ УМОВ ПІВДЕННОГО СТЕПУ УКРАЇНИ
}

\author{
РЕВТЬО О.Я. - кандидат сільськогосподарських наук, доцент \\ https://orcid.org/0000-0002-7990-3135 \\ Херсонський державний аграрно-економічний університет \\ ДОМАРАЦЬКИЙ Є.О. - доктор сільськогосподарських наук, доцент \\ https://orcid.org/0000-0003-3912-1611 \\ Херсонський державний аграрно-економічний університет
}

Постановка проблеми. Екстремально-посушливі умови Південного Степу України зумовлюють впроваджувати культури з високим рівнем адаптації, що сприяє оптимізації продукційного процесу агроценозів, ефрективному використанню ресурсів та отриманню якісної продукції. Екологічна пластичність і стабільність гібридів соняшнику є одними з визначальних чинників ефективного функціонування агроценозів. Лише гібриди з високим рівнем адаптивності здатні за низької забезпеченості опадами, ґрунтової вологи та високих температур реалізувати біологічний потенціал. Регулятори росту сприяють підвищенню пластичності соняшнику [9]. Виведення нових гібридів соняшнику викликає необхідність дослідження ефективності використання регуляторів росту рослин як у чистому вигляді, так і за інших умов.

Аналіз останніх досліджень і публікацій. Нині ефективність практичного застосування кращих регуляторів росту рослин підтверджена перевіркою у наукових установах та в сотнях передових і базових господарств [2; 3; 5; 8; 17].

Важливим аспектом дії регуляторів росту є підвищення стійкості рослин до несприятливих факторів навколишнього середовища, а саме високих та низьких температур, нестачі вологи, фітотоксичної дії пестицидів, пошкодження шкідниками та ураження хворобами, що, зрештою, сприяє значному підвищенню врожайності та зростанню якості продукції [13].

Дослідження з вивчення впливу регуляторів росту рослин Радостим та Трептолем і мікродобрива Квантум на урожайність та економічну ефективність під час вирощування ліній Сх1010А, Х526В, Х720B та гібридів Романс і Максимус соняшнику, проведені вченими Інституту рослинництва імені В.Я. Юр'єва в Харківській області, показали високу ефективність препаратів, яка залежить від способу їх застосування [11].

Дослідженнями, проведеними на дослідному полі ДВНЗ «Херсонський державний аграрний університет», встановлено, що регулятори росту Хелафіт Комбі, Мир та Міфосат за їх одноразового внесення під час вегетації соняшнику сприяли поліпшенню розвитку рослин, збільшували інтенсивність процесів росту на всіх етапах органогенезу завдяки активізації процесів росту, а також посилювали адаптаційні можливості культури до несприятливих кліматичних умов [17].

Дослідження Інституту мікробіології і вірусології НААН України показали, що за сумісного використання нових регуляторів росту з пестицидами для протруювання насіння їх дози внесення можна зменшувати на 20-30\% без зниження захисного ефекту, що забезпечує значну економію засобів [15].

Дослідженнями В.В. Калитки та Л.А. Покопцевої доведено, що антиоксидантний препарат дистинол (д. р. іонол та ДМСО) має позитивний вплив не тільки на врожайність соняшнику, але й на збереженість посівних якостей насіння у період зберігання [12].

Проведені дослідження вченими Інституту рослинництва імені В.Я. Юр'єва показали позитивний вплив передпосівної обробки на посівні якості насіння соняшнику. Передпосівна обробка насіння регуляторами росту рослин разом із протруйниками забезпечує підвищення лабораторної схожості партій насіння зі зниженими посівними якостями, а саме лінії Сх1010А від 4\% до 8\%; лінії X526В -від 4\% до 12\%; лінії Х720В - від $2 \%$ до $16 \%$ [18].

Мета статті полягає в оптимізації продукційного процесу агроценозів соняшнику за вирощування його в екстремально-посушливих умовах Південного Степу України.

Матеріали та методика досліджень. Для досягнення мети програмою наукових досліджень було передбачено закладання двохфакторного польового досліду відповідно до методики дослідної справи [7] впродовж 2017-2020 рр., де фрактором А були гібриди соняшнику Драган і Конгрес, оригінатором яких є Інститут рільництва і овочівництва м. Нові Сад (Сербія) та гібрид Тунка, оригінатор - компанія "LG" (Туреччина); фрактором В - еколого безпечні препарати, а саме стимулятори росту рослин Біогель, Хелафіт Комбі, Міфосат та Вуксал Мікроплант. Контрольний варіант передбачав обробіток рослин соняшника чистою водою. Польові досліди проводилися в умовах дослідного поля Херсонського державного аграрно-економічного університету (GPS: 46.69772846, 32.46125221) на темнокаштанових ґрунтах, які характеризуються потужністю гумусового горизонту 45-55 см та щільністю складання 1,25-1,35, щільність твердої фрази ґрунту становить 2,65-2,69 г/см³ , загальна шпаруватість складає 45-50\%, $\mathrm{pH}$ середовища становить 7,2-7,4. Водостійкі агрегати розміром більше 0,25 мм складають 40-42\%. Ґрунтові води залягають переважно на глибині 3-4 м і не беруть участі в його водному режимі.

Повторність у досліді $є$ триразовою, посівна площа ділянки першого порядку складала 168 м², облікової - 


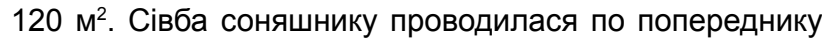
пшениця озима; агротехніка, крім досліджуваних факторів, загальноприйнята для зони Степу. Система удобрення передбачала внесення мінеральних добрив розкидним способом під основний обробіток ґрунту дозою $\mathrm{N}_{30} \mathrm{P}_{30} \mathrm{~K}_{30}$. Позакореневі обробітки рослин соняшника стимуляторами росту і чистою водою (контрольний варіант) проводили у фазу 8-10 справжніх листків наземним оприскувачем з виливом робочої рідини 240 л/га, норми внесення препаратів рекомендовані виробником для росту стимулюючих речовин.

Всі обліки і спостереження виконували відповідно до загальноприйнятих методик із проведення польових дослідів у рослинництві та сортовипробуванні, методичних рекомендацій Інституту рослинництва ім. В.Я. Юр'єва НААН [10; 14], наявних ДСТУ. Вологість ґрунту визначали термостатно-ваговим методом під час сівби та збирання культури.

Облік урожаю насіння проводили вручну з подальшим перерахунком врожайності в тони на гектар за стандартної вологості та на $100 \%$ чистоти.

Результати досліджень. Впродовж останніх років розвиток галузі рослинництва України досяг істотних успіхів у своєму розвитку. Насамперед необхідно відзначити позитивні тренди у збільшенні обсягів виробництва продукції рослинництва. Подібні тенденції є свідченням суттєвих інвестицій і капіталовкладень в інноваційні підходи до вдосконалення технологій вирощування основних польових культур та методів організації виробництва [6; 15]. Одним з основних лімітованих факторів реалізації потенційної урожайності соняшника в умовах Південного Степу України є дефіцит вологозабезпеченості агроценозів, усі агрозаходи, спрямовані на збереження вологи, $є$ головними в землеробстві степової зони [5]. Щодо погодних умов 2017-2020 рр. досліджень, то їх можна класифрікувати як середньо-посушливі типові для цієї зони вирощування. Основні погодні умови років досліджень порівняно із середньобагаторічними даними наведено на рис. $1,2$.

Аналізуючи погодні умови 2017-2020рр. досліджень, встановлюємо, що показники середньомісячної температури повітря були вищими за відповідні середньобагаторічні дані, особливо це стосується умов 2018 та 2020 рр. Високий температурний режим у період від сходів до фрази наливу насіння та низька вологість повітря обумовили інтенсивну витрату ґрунтової вологи на транспірацію та випаровування.

Щодо умов зволоження, то найбільш посушливими для вегетації рослин соняшника були 2017 та 2020 рр., 2018 і 2019 рр. можна вважати помірно посушливими,

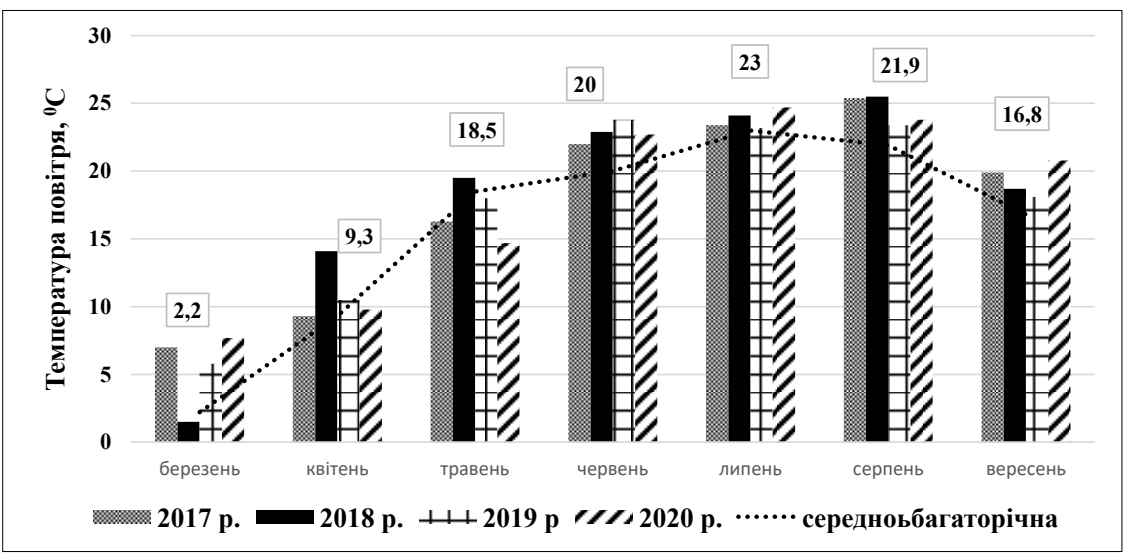

Рис. 1. Середньомісячна температура повітря за вегетаційний період вирощування соняшнику за 2017-2020 pp., ${ }^{\circ} \mathrm{C}$

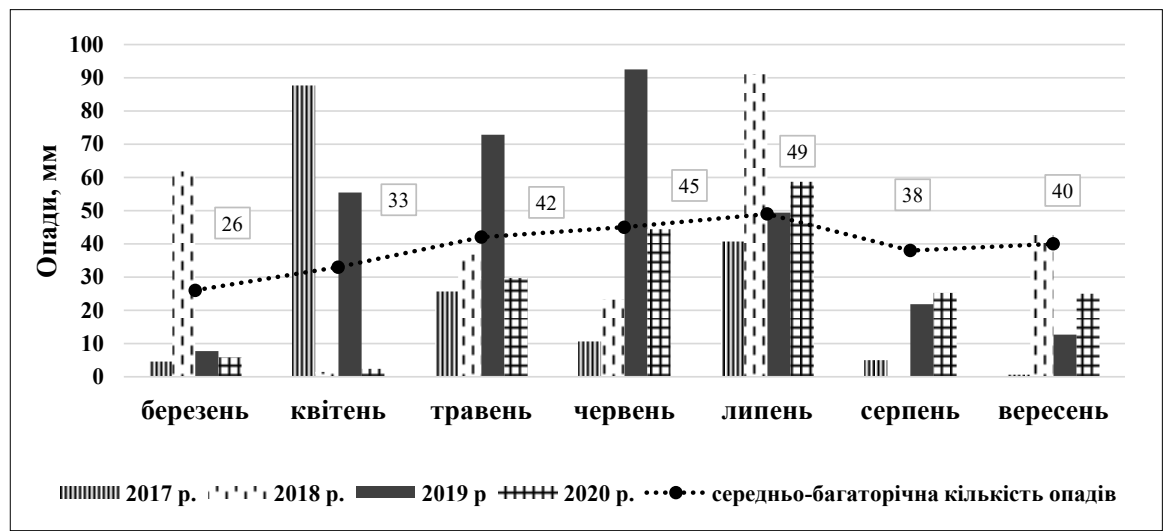

Puc. 2. Сума опадів за вегетаційний період вирощування соняшнику за 2017-2020 рр., м 
проте розподіл опадів був нерівномірним упродовж усього періоду росту і розвитку культури. Загалом погодні умови 2017 та 2020 рр. для росту і розвитку соняшнику були складними впродовж усього періоду вегетації культури.

Застосування рістрегулюючих препаратів є важливим засобом інтенсифікації сучасної технології вирощування соняшника. Невисокі норми внесення таких речовин, що дають змогу впливати на морфогенез та продукційний процес, підвищувати стійкість рослин до стресових факторів зовнішнього середовища, визначають їх перспек- тивність [1; 2; 4]. Результатами досліджень установлено, що обробіток соняшника на початкових етапах органогенезу стимуляторами росту по-різному впливав на біометричні показники рослин (табл. 1).

Аналіз результатів польового досліду свідчить про те, що позакореневі обробки соняшника стимуляторами росту не мали істотного впливу на висоту рослин, вона залежала від генетичних особливостей гібриду. Проте досліджувані препарати мали позитивний вплив на формування площі листового апарату і кількість листків на одній рослині. Усі досліджувані гібриди формували мак-

Таблиця 1 - Біометричні показники рослин соняшника у фазі цвітіння залежно від стимуляторів росту, середнє за 2017-2020 рр.

\begin{tabular}{|c|c|c|c|}
\hline Регулятори росту рослин & Висота рослин, см & $\begin{array}{l}\text { Кількість листків } \\
\text { на } 1 \text { рослині, шт. }\end{array}$ & 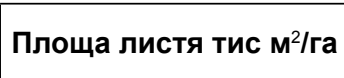 \\
\hline \multicolumn{4}{|l|}{ Драган } \\
\hline Вода (контроль) & 161 & 24 & 39,8 \\
\hline Біогель & 161 & 26 & 42,2 \\
\hline Хелафіт Комбі & 162 & 28 & 46,5 \\
\hline Мiфросат & 161 & 24 & 41,7 \\
\hline Вуксал Мікроплант & 162 & 26 & 45,0 \\
\hline \multicolumn{4}{|l|}{ Конгрес } \\
\hline Вода (контроль) & 164 & 26 & 40,5 \\
\hline Біогель & 164 & 26 & 44,8 \\
\hline Хелафріт Комбі & 163 & 30 & 49,0 \\
\hline Мiфосат & 164 & 28 & 43,1 \\
\hline Вуксал Мікроплант & 163 & 28 & 47,9 \\
\hline \multicolumn{4}{|l|}{ Тунка } \\
\hline Вода (контроль) & 152 & 22 & 46,2 \\
\hline Біогель & 152 & 24 & 49,7 \\
\hline Хелафріт Комбі & 153 & 26 & 52,5 \\
\hline Міфосат & 153 & 24 & 50,2 \\
\hline Вуксал Мікроплант & 152 & 24 & 51,3 \\
\hline
\end{tabular}

Таблиця 2 - Урожайність кондиційного насіння гібридів соняшника залежно від стимуляторів росту, т/га

\begin{tabular}{|c|c|c|c|c|c|c|}
\hline \multirow{2}{*}{$\begin{array}{c}\text { Регулятори росту рослин } \\
\text { (В) }\end{array}$} & \multicolumn{4}{|c|}{ Роки } & \multirow{2}{*}{$\begin{array}{c}\text { Середня за } \\
4 \text { роки }\end{array}$} & \multirow{2}{*}{$\begin{array}{l}\text { Збільшення } \\
\text { (зниження) } \pm \\
\text { до контролю }\end{array}$} \\
\hline & 2017 & 2018 & 2019 & 2020 & & \\
\hline \multicolumn{7}{|l|}{ Драган (A) } \\
\hline Вода (контроль) & 1,38 & 1,88 & 1,74 & 1,43 & 1,61 & - \\
\hline Біогель & 1,59 & 2,03 & 2,11 & 1,74 & 1,87 & $+0,26$ \\
\hline Хелафріт Комбі & 1,62 & 2,09 & 2,19 & 1,85 & 1,94 & $+0,33$ \\
\hline Мiфосат & 1,52 & 1,98 & 2,01 & 1,81 & 1,83 & $+0,22$ \\
\hline Вуксал Мікроплант & 1,74 & 2,14 & 2,28 & 1,98 & 2,04 & $+0,43$ \\
\hline \multicolumn{7}{|l|}{ Конгрес (A) } \\
\hline Вода (контроль) & 1,41 & 1,96 & 1,85 & 1,32 & 1,63 & - \\
\hline Біогель & 1,54 & 2,11 & 2,09 & 1,66 & 1,85 & $+0,22$ \\
\hline Хелафріт Комбі & 1,65 & 2,19 & 2,21 & 1,75 & 1,95 & $+0,32$ \\
\hline Міфосат & 1,56 & 2,13 & 2,20 & 1,61 & 1,88 & $+0,25$ \\
\hline Вуксал Мікроплант & 1,77 & 2,32 & 2,25 & 1,84 & 2,04 & $+0,41$ \\
\hline \multicolumn{7}{|l|}{ Тунка (A) } \\
\hline Вода (контроль) & 1,59 & 2,05 & 2,17 & 1,63 & 1,86 & - \\
\hline Біогель & 1,64 & 2,28 & 2,39 & 1,69 & 2,00 & $+0,14$ \\
\hline Хелафріт Комбі & 1,78 & 2,41 & 2,48 & 1,82 & 2,18 & $+0,32$ \\
\hline Miфосат & 1,70 & 2,35 & 2,31 & 1,68 & 2,01 & $+0,15$ \\
\hline Вуксал Мікроплант & 1,84 & 2,50 & 2,56 & 1,92 & 2,21 & $+0,35$ \\
\hline $\mathrm{HIP}_{05, \text { T/ra }} \mathrm{A} ; \mathrm{B} ; \mathrm{AB}$ & $\begin{array}{c}0,05 ; 0,06 \\
0,09\end{array}$ & $\begin{array}{c}0,06 ; 0,07 \\
0,09\end{array}$ & $\begin{array}{c}0,04 ; 0,06 ; \\
0,08\end{array}$ & $\begin{array}{c}0,03 ; 0,05 \\
0,07\end{array}$ & - & - \\
\hline
\end{tabular}


симальну площу листового апарату і кількість листків на одній рослині за умов внесення препарату Хелафіт Комбі під час фази цвітіння, дещо поступалися йому за ефрективністю Вуксал Мікроплант, Міфосат та Біогель. Максимальна площа листкової поверхні (52,5 тис. м²/га) була зафіксована у гібриду Тунка на варіанті обробітку рослин Хелафітом Комбі.

Інтегрованим показником, що відображає характер продукційного процесу агроценозу соняшника, який формується залежно від стимуляторів росту, є урожайність, а також елементи ії структури. Продуктивність посіву соняшника також залежить від сорто-гібридних особливостей рослин та їх передзбиральної кількості на одиниці площі. Результати польового досліду свідчать про те, що рістрегулюючі препарати мали позитивний вплив на посилення інтенсивності ростових процесів культури, а також розвитку агроценозу загалом як результат і підвищення його продуктивності (табл. 2).

Аналізом цих польових досліджень установлено, що впродовж 2017-2020 рр. найбільшу урожайність загалом формував гібрид Тунка. Дещо поступалися йому за рівнем продуктивності гібриди Конгрес і Драган, які в гостро посушливі 2017 та 2020 рр. істотно знижували рівень урожайності порівняно з гібридом Тунка. Проте реакція гібридів на досліджувані стимулятори росту рослин була неоднаковою.

Позакореневі обробки рослин соняшника стимуляторами росту мали тенденцію до підвищення врожайності порівняно з контрольним варіантом за всіма досліджуваними гібридами. Так, у середньому за чотири роки проведення досліджень показники прибавки урожайності до контрольного варіанта коливалися у межах від 0,14 до 0,43 т/га. Найменшого рівня приросту урожайності 0,14 т/га від стимуляторів росту зафріксовано у гібриду Тунка на варіанті обробітку рос- лин Біогелем, а найвищого (0,43 т/га) - у гібриду Драган у варіанті обробітку соняшника препаратом Вуксал Мікроплант. Характерним $\epsilon$ те, що в більш сприятливі 2018 та 2019 рр. за вологозабезпеченістю вплив стимуляторів росту на фрормування урожайності соняшника був більш суттєвим порівняно з гостро посушливими 2017 та 2020 pp.

Найбільш стабільні показники приросту урожайності зі всіма гібридами зафріксовано у варіантах обробітку рослини соняшника Хелафітом Комбі, які коливалися у межах 0,32-0,33 т/га.

Найвищим рівнем урожайності, а саме 2,21 т/га в середньому за роками проведення досліджень, характеризувався гібрид Тунка за умов обробітку рослин Вуксалом Мікроплант, а найнижчим (1,83 т/га) - гібрид Драган за обробки стимулятором росту Міфосат.

Програмою наукових досліджень було передбачено визначення структурних показників урожаю гібридів соняшнику, а саме діаметру суцвіття, маси 1000 насінин та маси насіння з кошику (табл. 3).

Обробіток рослин соняшника стимуляторами росту мав позитивний вплив на структурні показники урожаю досліджуваних гібридів. Так, діаметр суцвіття під впливом стимуляторів росту мав тенденцію до збільшення, максимальним він був за умов обробки рослин Вуксалом Мікроплант і Хелафітом Комбі. Щодо маси 1000 насінини, то рістрегулюючі речовини сприяли формуванню більш крупного насіння гібридів Драган і Конгрес, у гібриду Тунка залежність крупності насіння від препаратів була дещо меншою. Максимальною маса 1000 насінин була встановлена у гібриду Тунка (74,1 г) за умов внесення препарату Вуксал Мікроплант.

Maca насіння 3 кошику досліджуваних гібридів також змінювалася під впливом стимуляторів росту. Так, у гібридів соняшнику Конгрес і Драган збільшився

Таблиця 3 - Показники структури урожаю насіння соняшника залежно від стимуляторів росту, середнє за 2017-2020 рр.

\begin{tabular}{|c|c|c|c|c|c|c|}
\hline $\begin{array}{c}\text { Регулятори росту } \\
\text { рослин }\end{array}$ & $\begin{array}{c}\text { Діаметр } \\
\text { суцвіття, см }\end{array}$ & $\begin{array}{c} \pm \text { до } \\
\text { контролю }\end{array}$ & $\begin{array}{c}\text { Мaca } 1000 \\
\text { насінин, г }\end{array}$ & $\begin{array}{c} \pm \text { до } \\
\text { контролю }\end{array}$ & $\begin{array}{c}\text { Маса насіння } \\
\text { з кошику, г }\end{array}$ & $\begin{array}{c} \pm \text { до } \\
\text { контролю }\end{array}$ \\
\hline \multicolumn{7}{|c|}{ Драган } \\
\hline Вода (контроль) & 17,2 & - & 64,3 & - & 40,3 & - \\
\hline Біогель & 18,4 & $+1,2$ & 68,2 & $+3,9$ & 46,7 & $+6,4$ \\
\hline Хелафріт Комбі & 19,1 & $+1,9$ & 68,6 & $+4,3$ & 48,5 & $+8,2$ \\
\hline Міфосат & 17,9 & $+0,7$ & 67,8 & $+3,5$ & 45,7 & $+5,4$ \\
\hline Вуксал Мікроплант & 18,8 & $+1,6$ & 70,5 & $+6,2$ & 51,0 & $+10,7$ \\
\hline \multicolumn{7}{|c|}{ Конгрес } \\
\hline Вода (контроль) & 16,4 & - & 66,1 & - & 40,7 & - \\
\hline Біогель & 17,6 & $+1,2$ & 68,2 & $+2,1$ & 46,3 & $+5,6$ \\
\hline Хелафріт Комбі & 18,9 & $+2,5$ & 69,3 & $+3,2$ & 48,8 & $+8,1$ \\
\hline Міфосат & 18,0 & $+1,6$ & 67,7 & $+1,6$ & 47,0 & $+6,3$ \\
\hline Вуксал Мікроплант & 19,3 & $+2,9$ & 69,1 & $+3,0$ & 50,9 & $+10,2$ \\
\hline \multicolumn{7}{|c|}{ Тунка } \\
\hline Вода (контроль) & 15,2 & - & 72,0 & - & 46,5 & - \\
\hline Біогель & 17,4 & $+2,2$ & 73,1 & $+1,1$ & 50,0 & $+3,5$ \\
\hline Хелафріт Комбі & 17,8 & $+2,6$ & 73,4 & $+1,4$ & 54,5 & $+8,0$ \\
\hline Міфосат & 17,0 & $+1,8$ & 72,9 & $+0,9$ & 50,3 & $+3,8$ \\
\hline Вуксал Мікроплант & 18,9 & $+3,7$ & 74,1 & $+2,1$ & 55,3 & $+8,8$ \\
\hline
\end{tabular}


збір насіння з кошику на 10,2 та 10,7 г відповідно порівняно 3 контрольним варіантом за умов обробки рослин Вуксалом Мікроплант. Найменший приріст збору насіння 3 кошику (+3,5 г) було зафіксовано у гібриду Тунка на варіанті внесення препарату Біогель.

Висновки. Позакореневі обробітки рослин соняшника у фразі 8-10 справжніх листків досліджуваними стимуляторами росту не мали істотного впливу на висоту рослин, вона залежала від генетичних особливостей гібриду. Проте досліджувані препарати мали позитивний вплив на формування площі листового апарату і кількість листків на одній рослині. Максимальна площа листкової поверхні (52,5 тис.м²/га) була зафіксована у гібриду Тунка на варіанті обробітку рослин Хелафітом Комбі.

Найбільшу урожайність загалом формував гібрид Тунка. Дещо поступалися йому за рівнем продуктивності гібриди Конгрес і Драган, які в гостро посушливі 2017 та 2020 рр. істотно знижували рівень урожайності порівняно з гібридом Тунка. Найвищим рівнем урожайності, а саме 2,21 т/га в середньому за роками проведення досліджень, характеризувався гібрид Тунка за умов обробітку рослин Вуксалом Мікроплант, а найнижчим (1,83 т/га) гібрид Драган за обробки стимулятором росту Міфосат.

Обробка рослин рістрегулюючими речовинами сприяла фрормуванню більш крупного насіння усіх досліджуваних гібридів. Максимальною маса 1000 насінин була встановлена у гібриду Тунка (74,1 г) за умов внесення препарату Вуксал Мікроплант. У гібридів соняшнику Конгрес і Драган збільшився збір насіння з кошику на 10,2 та 10,7 г відповідно порівняно з контрольним варіантом за умов обробки рослин Вуксалом Мікроплант. Найменший приріст збору насіння з кошику (+3,5 г) було зафіксовано у гібриду Тунка на варіанті внесення препарату Біогель.

Проведені багаторічні польові дослідження дають можливість стверджувати, що позакореневий обробіток рослин стимуляторами росту може бути дієвим механізмом оптимізації продукційного процесу агроценозів соняшнику за вирощування його в екстремально-посушливих умовах Південного Степу України.

\section{СПИСОК ВИКОРИСТАНОÏ ЛІТЕРАТУРИ:}

1. Базалій В.В., Домарацький Є.О., Козлова О.П., Домарацький О.О. Вплив стимуляторів росту та біофунгіцидів на архітектоніку різних морфобіотипів соняшника. Техніка $і$ технології АПК. 2019. Вип. 2 (111). С. 24-28.

2. Базалій В., Домарацький Є., Козлова О. Вплив біофунгіцидів і стимуляторів росту на продуктивність соняшнику та якість олійної сировини. Зрошуване землеробство. 2019. Вип. 71. С. 5-10.

3. Гангур В.В., Єремко Л.С., Кочерга А.А. Ефективність біостимуляторів за умови передпосівної обробки насіння соняшнику. Вісник Полтавської державної аграрної академії. 2020. № 2. C. 36-42. URL: https://doi.org/10.31210/visnyk2020.02.04.

4. Добровольський А.В., Домарацький Є.О. Особливост реалізації стимулюючої дії комплексних препаратів рослинами соняшника на початкових етапах органогенезу. Аграрний вісник Причорномор'я. 2017. Вип. 84-2. С. 39-45.

5. Домарацький Є.О., Добровольський А.В., Домарацький О.О. Вплив багатофункціональних рістрегулюючих препаратів на формування продуктивності гібридів соняшнику високоолеїнового типу. Таврійський науковий вісник. 2020. Вип. 115. С. 32-41.

6. Домарацький Є.О., Козлова О.П. Економічне обґрунтування використання екологобезпечних препаратів у технологічних схемах вирощування соняшника. Таврійський науковий вісник. 2020. Вип. 111. С. 60-68.

7. Доспехов Б.А. Методика полевого опыта (с основами статистической обработки результатов исследований). Москва : Колос, 1985. 336 с.

8. Буряк Ю.І. та ін. Ефективність застосування регуляторів росту рослин та мікродобрива в насінництві соняшнику. Вісник ЦНЗ АПВ Харківської області. 2014. № 16. C. 20-25.

9. Єременко О.А. Агробіологічні основи формування продуктивності олійних культур (Helianthus annuus L., Carthamus tinctorius L., Linum usitatissimum L.) в Південному Степу України : дис. ... докт. с.-г. наук : спец. 06.01.09. Київ ; Мелітополь, 2018. 402 с.

10. Кириченко В.В., Чехов А.В., Петренкова В.П. Визначення оптимальних параметрів виробництва олійних культур : методичні рекомендації. Харків : Інститут рослинництва ім. В.Я. Юр'єва HAAH, 2012. 88 c.

11. Клименко I.I. Вплив регуляторів росту рослин і мікродобрив на урожайність насіння ліній та гібридів соняшник. Селекція та насінництво. 2015. Вип. 107. С. 183-188.

12. Покопцева Л.А., Калитка В.В. Вплив антиоксиданту дистинол на формування насіння соняшнику в умовах півдня України. Збірник наукових праць Луганського національного аграрного універсиmemy. 2006. № 57. C. 73-78.

13. Пономаренко С.П. Регуляторы роста растений Киев, 2003. 312 с.

14. Попов С.І., Кириченко В.В., Козубенко Л.В. Визначення біологічної врожайності кукурудзи та соняшнику : методичні рекомендації. Харків : Інститут рослинництва ім. В.Я. Юр'єва НААН, 2014. 16 c.

15. Черячукін М.В., Андрієнко О.М., Григор'єва О.С. Регулятори росту рослин. Агробізнес Сьогодні. 2011. URL: http://agro-business.com.ua/ agro/ahronomiia-sohodni/item/109-rehuliatory-rosturoslyn.html.

16. Шиян Д.В., Гончарова К.І. Інноваційна складова при виробництві соняшнику. Сучасні інноваційно-інвестиційні механізми розвитку національної економіки в умовах євроінтеграції : матеріали VII міжнародної науково-практичної інтернет-конференції, 29 жовтня 2020 р. Полтава : Полтавська політехніка ім. Юрія Кондратюка, 2020. С. 69-70.

17. Domaratskiy Y. et al. Research Of The Impact Of Growth Regulators Application On The Basic Biometric, Structural Indicators And Formation Of Sunflower Hybrids Seed Performance In The Southern Zones Of Ukraine Under The Conditions Of Global Climate Transformations. Research Journal of Pharmaceutical, Biological and Chemical Sciences. 2018. № 9(3). P. 1022-1029. 
18. Буряк Ю.І. та ін. Sowing quality of seeds sunflower, depending on the influence of plant growth regulators and protectants. Plant Breeding and Seed Production. 2014. № 105. P. 173-177. URL: https:// doi.org/10.30835/2413-7510.2014.42072.

\section{REFERENCES:}

1. Bazalii V.V., Domaratskyi Ye.O., Kozlova O.P., Domaratskyi O.O. (2019). Vplyv stymuliatoriv rostu ta biofunhitsydiv na arkhitektoniku riznykh morfobiotypiv soniashnyka [Influence of growth stimulants and biofungicides on the architecture of different morphobiotypes of sunflower]. Kiev: Tekhnika i tekhnolohii APK [in Ukrainian].

2. Bazalii V.V., Domaratskyi Ye.O., Kozlova O.P. (2019). Vplyv biofunhitsydiv i stymuliatoriv rostu na produktyvnist soniashnyku ta yakist oliinoi syrovyny [Influence of biofungicides and growth stimulants on sunflower productivity and quality of oil raw materials]. Kherson: Zroshuvane zemlerobstvo [in Ukrainian].

3. Hanhur V.V., Yeremko L.S., Kocherha A.A. (2020). Efektyvnist biostymuliatoriv za umovy peredposivnoi obrobky nasinnia soniashnyku [The effectiveness of biostimulants under pre-sowing treatment of sunflower seeds]. Poltava: Visnyk Poltavskoi derzhavnoi ahrarnoi akademii [in Ukrainian].

4. Dobrovolskyi A.V., Domaratskyi Ye.O. (2017). Osoblyvosti realizatsii stymuliuiuchoi dii kompleksnykh preparativ roslynamy soniashnyka na pochatkovykh etapakh orhanohenezu [Features of realization of stimulating action of complex preparations by sunflower plants at the initial stages of organogenesis]. Odessa: Ahrarnyi visnyk Prychornomoria [in Ukrainian].

5. Domaratskyi Ye.O., DobrovolskyiA. V., Domaratskyi O.O. (2020). Vplyv bahatofunktsionalnykh ristrehuliuiuchykh preparativ na formuvannia produktyvnosti hibrydiv soniashnyku vysokooleinovoho typu [Influence of multifunctional growth-regulating drugs on the formation of productivity of high-oleic type sunflower hybrids]. Kherson: Tavriiskyi naukovyi visnyk [in Ukrainian].

6. Domaratskyi Ye.O., Kozlova O.P. (2020). Ekonomichne obgruntuvannia vykorystannia ekolohobezpechnykh preparativ u tekhnolohichnykh skhemakh vyroshchuvannia soniashnyka [Economic justification of the use of environmentally friendly drugs in technological schemes of sunflower cultivation]. Kherson: Tavriiskyi naukovyi visnyk [in Ukrainian].

7. Dospekhov B.A. (1985). Metodyka polevoho opyta (s osnovamy statystycheskoi obrabotky rezultatov yssledovanyi) [Methods of field experience (with the basics of statistical processing of research results)]. Moskva: Kolos [in Russian].

8. Buriak Yu.I. (2014). Efektyvnist zastosuvannia rehuliatoriv rostu roslyn ta mikrodobryva $v$ nasinnytstvi soniashnyku [The effectiveness of plant growth regulators and microfertilizers in sunflower seed production]. Kharkiv: Visnyk TsNZ APV Kharkivskoi oblasti [in Ukrainian].

9. Yeremenko O.A. (2018). Ahrobiolohichni osnovy formuvannia produktyvnosti oliinykh kultur (Helianthus annuus L., Carthamus tinctorius L., Linum usitatissimum L.) v Pivdennomu Stepu Ukrainy [Agrobiological bases of formation of productivity of oilseeds (Helianthus annuus L., Carthamus tinctorius L., Linum usitatissimum L.) in the Southern Steppe of Ukraine]: dys. ... d-ra s.-h. nauk : 06.01.09. Kyiv-Melitopol [in Ukrainian].

10. Kyrychenko V.V., Chekhov A.V., Petrenkova V.P. (2012). Vyznachennia optymalnykh parametriv vyrobnytstva oliinykh kultur: metodychni rekomendatsii [Determination of optimal parameters of oilseeds production: methodical recommendations]. Kharkiv. Instytut roslynnytstva im. V.la. Yurieva NAAN [in Ukrainian].

11. Klymenko I.I. (2015). Vplyv rehuliatoriv rostu roslyn i mikrodobryv na urozhainist nasin-nia linii ta hibrydiv soniashnyku [Influence of plant growth regulators and microfertilizers on seed yields of sunflower lines and hybrids]. Kiev: Selektsiia ta nasinnytstvo [in Ukrainian].

12. Pokoptseva L.A., Kalytka V.V. (2006). Vplyv antyoksydantu dystynol na formuvannia nasinnia soniashnyku $v$ umovakh pivdnia Ukrainy [The effect of the antioxidant distinol on the formation of sunflower seeds in the south of Ukraine]. Luhansk: Zbirnyk naukovykh prats Luhanskoho natsionalnoho ahrarnoho universytetu [in Ukrainian].

13. Ponomarenko S.P. (2003). Rehuliatory rosta rastenyi [Plant growth regulators]. Kiev [in Ukrainian].

14. Popov S.I., Kyrychenko V.V, Kozubenko L.V. (2014). Vyznachennia biolohichnoi vrozhainosti kukurudzy ta soniashnyku: metodychni rekomendatsii [Determination of biological yield of corn and sunflower: guidelines]. Kharkiv. Instytut roslynnytstva im. V.la. Yurieva NAAN [in Ukrainian].

15. Cheriachukin M.V. (2011). Rehuliatory rostu roslyn [Plant growth regulators]. Kiev: Ahrobiznes Sohodni [in Ukrainian].

16. Shyian D.V., Honcharova K.I. (2020). Innovatsiina skladova pry vyrobnytstvi soniashnyku [Innovative component in the production of sunflower]. Suchasni innovatsiino-investytsiini mekhanizmy rozvytku natsionalnoi ekonomiky $v$ umovakh yevrointehratsii: materialy VII mizhnar. naukovo-prakt. Internet-konf. Poltava: Poltavska politekhnika im. Yuriia Kondratiuka [in Ukrainian].

17. Domaratskiy Y. (2018). Research Of The Impact Of Growth Regulators Application On The Basic Biometric, Structural Indicators And Formation Of Sunflower Hybrids Seed Performance In The Southern Zones Of Ukraine Under The Conditions Of Global Climate Transformations. Research Journal of Pharmaceutical, Biological and Chemical Sciences [in India].

18. Buriak Yu.l. (2014). Sowing quality of seeds sunflower, depending on the influence of plant growth regulators and protectants. Kharkiv: Plant Breeding and Seed Production [in Ukrainian].

Ревтьо О.Я., Домарацький Є.О. Оптимізація продукційного процесу агроценозів соняшнику за посушливих умов Південного Степу України

Мета статті полягає в оптимізації продукційного процесу агроценозів соняшнику за вирощування його в екстремально-посушливих умовах Південного Степу України.

Методи. У процесі досліджень були використані такі методи: історичний (для узагальнення наукових досягнень вчених щодо оптимізації продукційного процесу агроценозів соняшнику); польовий багаторічний двофракторний дослід (для визначення біометричних 
показників та врожаю культури); лабораторний (для аналізу структури та якості врожаю насіння); статистичний (для проведення дисперсійного аналізу результатів досліджень).

Результати. За результатами узагальнення багаторічних даних польових досліджень установлено, що обробіток соняшника на початкових етапах органогенезу стимуляторами росту по-різному впливав на біометричні показники рослин. Позакореневі обробки соняшника стимуляторами росту не мали істотного впливу на висоту рослин, вона залежала від генетичних особливостей гібриду. Проте досліджувані препарати мали позитивний вплив на формування площі листового апарату і кількість листків на одній рослині. Усі досліджувані гібриди формували максимальну площу листового апарату і кількість листків на одній рослині за умов внесення препарату Хелафріт Комбі у фазу цвітіння. Максимальна площа листкової поверхні (52,5 тис.м²/га) була зафіксована у гібриду Тунка на варіанті обробітку рослин Хелафрітом Комбі.

Аналізом даних польових досліджень установлено, що впродовж 2017-2020 рр. найбільшу урожайність загалом формував гібрид Тунка. Реакція гібридів на досліджувані стимулятори росту рослин була неоднаковою. Позакореневі обробки рослин соняшника стимуляторами росту мали тенденцію до підвищення врожайності порівняно з контрольним варіантом за всіма досліджуваними гібридами. В середньому за чотири роки проведення досліджень показники прибавки урожайності до контрольного варіанта коливалися в межах від 0,14 т/га до 0,43 т/га. Найвищого рівня приросту урожайності, а саме 0,43 т/га, від стимуляторів росту зафріксовано у гібриду Драган у варіанті обробітку соняшника препаратом Вуксал Мікроплант. В більш сприятлив 2018 та 2019 рр. за вологозабезпеченістю вплив стимуляторів росту на формування урожайності соняшника був більш суттєвим порівняно з гостро посушливими 2017 та 2020 рр. Найвищим рівнем урожайності, а саме 2,21 т/га в середньому за роками проведення досліджень, характеризувався гібрид Тунка за умов обробітку рослин Вуксалом Мікроплант

Обробіток рослин соняшника стимуляторами росту мав позитивний вплив на структурні показники урожаю досліджуваних гібридів. Діаметр суцвіття під впливом стимуляторів росту мав тенденцію до збільшення, максимальним він був за умов обробки рослин Вуксалом Мікроплант і Хелафітом Комбі. Максимальною маса 1000 насінин була встановлена у гібриду Тунка $(74,1$ г) за умов внесення препарату Вуксал Мікроплант.

Висновки. Проведені багаторічні польові дослідження дають можливість стверджувати, що позакореневий обробіток рослин стимуляторами росту може бути дієвим механізмом оптимізації продукційного процесу агроценозів соняшнику за вирощування його в екстремально-посушливих умовах Південного Степу України.

Ключові слова: гібриди соняшнику, Драган, Конгрес, Тунка, стимулятори росту, Вуксал Мікроплант, Хелафріт Комбі, Біогель, Міфосат.

Revto O.Ya., Domaratskyi Ye.O. Optimization of the production process of sunflower agrocenoses under dry conditions of the Southern Steppe of Ukraine

The purpose of the research is to optimize the production process of sunflower agrocenoses under extreme dry conditions of the Southern Steppe of Ukraine.
Methods. The following methods were applied in the research process: historical - to generalize scientific achievements presented in the studies on optimization of the production process of sunflower agrocenoses; a multi-year field two-factor experiment - to determine biometric indexes and the crop yield; laboratory - to analyze the structure and quality of the seed yield; statistical - to perform dispersion analysis of the research results.

Results. The results generalizing the multi-year data of the field research allowed establishing that treatment of sunflower plants at the initial stages of organogenesis with growth stimulators had a different impact on biometric indexes of the plants. Foliar treatment of sunflower plants with growth stimulators did not have a substantial impact on the plant height and it depended on genetic characteristics of the hybrid. However, the preparations under study had a positive impact on the formation of the leaf area and the number of leaves per plant. All the hybrids under study had maximum leaf area and the number of leaves per plant provided that the preparation Khelafit Kombi was applied at the phase of blooming. The maximum leaf surface area of 52.5 thousand $\mathrm{m}^{2} /$ ha was registered in the hybrid Tunca in the variant of treating plants with Khelafit Kombi.

Analysis of the field research data made it possible to determine that the hybrid Tunca formed the highest productivity in 2017-2020. The reaction of the hybrids to the plant growth stimulators under study was different. Foliar treatment of sunflower plants with growth stimulators had a tendency to increase productivity in comparison with the test variant by all the hybrids under study. The indexes of an increase in the productivity in comparison with the test variant ranged from 0.14 to $0.43 \mathrm{t} /$ ha on the average for four years of the research. The highest increase in the productivity of $0.43 \mathrm{t} / \mathrm{ha}$ due to the growth stimulators was observed in the hybrid Drahan, in the variant of treating sunflower plants with the preparation Wuxal Microplant. The impact of growth stimulators on the formation of sunflower productivity was more substantial in 2018 and 2019 - the years more favorable in terms of moisture supply in comparison with very dry years of 2017 and 2020. On the average for the years of the research, the highest productivity of $2.21 \mathrm{t} /$ ha was characteristic of the hybrid Tunca provided that the plants were treated with Wuxal Microplant.

Treatment of sunflower plants with growth stimulators had a positive impact on the yield structure indexes of the hybrids under study. The inflorescence diameter had a tendency to increase under the influence of growth stimulators. It was maximum when the plants were treated with Wuxal Microplant and Khelafit Kombi. The maximum weight of 1000 seeds was registered in the hybrid Tunca $74.1 \mathrm{~g}$ provided that the preparation Wuxal Microplant was applied.

Conclusions. The multi-year field research allows maintaining that foliar treatment of plants with growth stimulators can be an efficient mechanism of optimization of the production process of sunflower agrocenoses under extreme dry conditions of the Southern Steppe of Ukraine.

Key words: sunflower hybrids, Drahan, Konhres, Tunca, growth stimulators, Wuxal Microplant, Khelafit Kombi, Biohel, Mifosat. 